\title{
NOTE
}

\section{First outbreak of sleeping disease in Switzerland: disease signs and virus characterization}

\author{
Heike Schmidt-Posthaus ${ }^{1, *}$, Nicolas Diserens ${ }^{1}$, Monika Jankowska Hjortaas ${ }^{2}$, \\ Ralph Knüsel $^{3}$, Regula Hirschi ${ }^{1}$, Torunn Taksdal ${ }^{2}$ \\ ${ }^{1}$ Centre for Fish and Wildlife Health, Department of Infectious Disease and Pathobiology, University of Berne, \\ Laenggassstrasse 122, PO Box 8466, 3001 Berne, Switzerland \\ ${ }^{2}$ Norwegian Veterinary Institute, Ullevålsveien 68, PO Box 750 Sentrum, 0106 Oslo, Norway \\ ${ }^{3}$ Fishdoc GmbH, Schaubhus, 6026 Rain, Switzerland
}

\begin{abstract}
Sleeping disease is a contagious disease mainly of freshwater farmed rainbow trout, caused by salmonid alphavirus (SAV) Subtype 2. Here we describe the first case in Switzerland. Pathological changes ranged from acute pancreas necrosis to more chronic lesions with complete loss of exocrine pancreas and simultaneous degenerative, inflammatory and regenerative heart and muscle lesions. The partial sequencing of SAV E2 and nsp3 genes placed the Swiss SAV variant within the Subtype 2 clustering together with freshwater isolates from UK and continental Europe. Although mortality stayed low, growth rates were significantly reduced, making the disease economically relevant.
\end{abstract}

KEY WORDS: Sleeping disease - Salmonid alphavirus · SAV · Subtype 2 - Pathology · Trout • Phylogenetic analysis

Resale or republication not permitted without written consent of the publisher

\section{INTRODUCTION}

Sleeping disease (SD) is a contagious disease mainly of freshwater farmed rainbow trout (Boucher \& Baudinn-Laurencin 1994, Boucher et al. 1995, McLoughlin \& Graham 2007, Lester et al. 2011). The syndrome has many similarities to pancreas disease (PD), a serious condition of farmed Atlantic salmon and rainbow trout in seawater (Munro et al. 1984, Taksdal et al. 2007). Recent studies have shown that SD and PD are caused by the same virus identified as salmonid alphavirus (SAV), in the family Togaviridae (Weston et al. 1999, 2002). Six SAV subtypes have been classified so far. SAV Subtypes 1, 2, 4, 5, and 6 have been isolated from fish affected by PD in Ireland and Scotland (Weston et al. 2005, Fringuelli et al. 2008, Lester et al. 2011). SAV Subtype 3 has only been found in Norway (Hodneland et al. 2005, Weston et al. 2005, Karlsen et al. 2006, Fringuelli et al. 2008). Recently, a marine SAV Subtype 2 was detected in Atlantic salmon in Scotland (Fringuelli et al. 2008) and Norway (Hjortaas et al. 2013). Although now isolated from Atlantic salmon in the seawater phase, the majority of outbreaks due to SAV Subtype 2 occur in freshwater rainbow trout causing SD (Castric et al. 1997, Fringuelli et al. 2008). SD has been observed in France for many years (Boucher \& Baudin-Laurencin 1994), and subsequently it was diagnosed in Croatia, Italy, Spain, Germany, England and Scotland (Branson 2002, Graham et al. 2003, McLoughlin \& Graham 2007, Vardic Smrzlić et al. 2013). All sizes and ages of freshwater rainbow trout are susceptible; however, mortality mainly occurs in fingerlings. Older fish may be infected without showing any clinical signs of disease. In natural outbreaks, mortality can vary between 3 and $22 \%$ (Graham et al. 2003). There is no evidence to date that surviving fish become long-term carriers. 
The most characteristic sign of the disease is the unusual behaviour of the fish, which stay on their side at the bottom of the tank. Histological examinations of SD-affected fish reveal a chronological appearance of lesions (Graham et al. 2007). Initially, necrosis of exocrine pancreas appears shortly before degeneration of heart muscle fibres. Later, skeletal muscle degeneration, necrosis and inflammation develop. The red muscle damage is particularly severe in the late stage of the disease and is probably responsible for the clinical signs of disease (Boucher et al. 1995, Boucher \& Baudin-Laurencin 1996, Kerbart Boscher et al. 2006).

Here we report the first case of SD in Switzerland. Clinical and pathological signs are reported. The molecular characterization of the virus is shown, including the relationship with SAV from fish farms in other European countries.

\section{MATERIALS AND METHODS}

In June 2013, a fish farmer reported rainbow trout lying on their side at the bottom of the tank. The fish originated from imported eggs from a fish farm in Denmark (free of notifiable diseases and sleeping disease). At a weight of about $15 \mathrm{~g}$, fish were moved to a part recirculation system with $90 \%$ spring water and $10 \%$ creek water. After about $3 \mathrm{wk}$, the signs mentioned above became obvious. A sample of 10 rainbow trout was sent alive to the Centre for Fish and Wildlife Health for pathological investigation. Time schedule of disease signs and sampling is shown in Fig. 1. Fish were euthanized in buffered 3aminobenzoic acid ethyl ester (MS-222 ${ }^{\circledR}$, Argent Chemical Laboratories). Each trout was measured, followed immediately by a standard necropsy. Fish were examined for changes in external and internal organs. For parasitological examination, a skin scraping, a gill sample and the intestinal content were

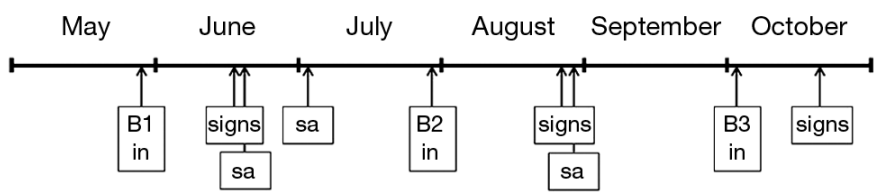

Fig. 1. Time line (2013) representing the chronology of introduction of fish in the part recirculation system, time point of first recognition of clinical signs of disease on farm and time point of sampling for diagnostics. $\mathrm{B}(\mathrm{n})$ in: number of the batch (Batch 1, B1; Batch 2, B2; Batch 3, B3) introduced into the recirculation system; signs: first recognition of disease signs on farm; sa: sampling for examination investigated by light microscopy. On 3 animals a bacteriological examination of liver, spleen and kidney was performed using blood agar plates (Bio Merieux) and bromothymol blue-lactose-agar plates. To examine for Flavobacteria, samples of gill and spleen were cultivated on specific agar plates (Anacker \& Ordal 1959). For virological examination, tissues from the gill, heart, head kidney, brain and pyloric caeca including pancreas of 5 fish were pooled as one sample. Antibiotic solution was added (1:10). Following a homogenisation of the tissue the solution was centrifuged at $1200 \times g$ and $4^{\circ} \mathrm{C}$ for $20 \mathrm{~min}$. Half of the supernatant was further diluted with antibiotic solution (1:10). Both dilutions were incubated on bluegill fry (BF-2) and epithelioma papulosum cyprini cells (EPC) for 2 passages each of $7 \mathrm{~d}$ at $15^{\circ} \mathrm{C}$. Gill, heart, kidney, liver and pyloric caeca including pancreas from several fish were removed and fixed in $10 \%$ buffered formalin for histopathological examination. Fixed samples were paraffin embedded, sections were cut, stained with haematoxylin-eosin (H\&E) and examined by light microscopy.

In July 2013, 9 animals originating from the same batch as the previous one were sent for necropsy (Fig. 1). Additional to the methods mentioned above, muscle tissue was fixed in $10 \%$ buffered formalin for histopathological examination

Because of the diagnosis of secondary parasitic and bacterial infections in these animals, different baths with disinfection agents against Ichthyophthirius multifiliis and Flavobacteria, were performed on the fish farm without success. The surviving fish were killed. The system was disinfected and was kept empty for $14 \mathrm{~d}$.

A second batch of fingerlings with average weight $25 \mathrm{~g}$ (eggs from Denmark) was then introduced to the same system (Fig. 1). In August 2013, 4 wk after introduction, 13 of these fish were examined in the same way as described above (Fig. 1). Additionally, samples of gills, heart, head kidney, brain and caeca pylorica including pancreas were placed in a RNA stabilization reagent, RNAlater ${ }^{\circledR}$ (Ambion), and nucleic acid extraction was performed using the RNeasy Mini Kit ${ }^{\circledR}$ (Qiagen) following the manufacturer's instructions. The nucleic acid yield was determined by spectrophotometry using the NanoDrop photometer (Witec AG). A conventional reverse transcription polymerase chain reaction (RT-PCR) specific for SD virus (SDV) was performed according to Villoing et al. $(2000 a, b)$. Primers for the amplification of a 284 base pair (bp) fragment were derived from the published SDV nucleotide sequence (Villoing et al. 
2000a; GenBank accession number AJ238578). As a positive control, RNA of cultured SAV 3, from the Norwegian Veterinary Institute, Oslo, Norway, was used. The PCR-amplification products were analyzed by agarose gel electrophoresis and amplification products were visualized using SYBR Green I staining (Molecular Probes). To test the specificity of the PCR and to exclude other differential diagnoses, namely infectious pancreatic necrosis virus (IPNV), a RT-PCR specific for IPNV was performed according to Taksdal et al. (2001). As a positive control, RNA of cultured IPNV was used.

For verification and further characterization of the virus, tissue samples were examined at the Norwegian Veterinary Institute in Oslo. Total nucleic acid from 4 tissue samples from 13 animals collected in RNAlater ${ }^{\circledR}$ (Ambion), was then extracted using the automatic extraction instrument NucliSense ${ }^{\circledR}$ easyMag $^{\mathrm{TM}}$ (bioMérieux bv). The samples were analysed for the presence of SAV by real-time RT-PCR (Villoing et al. 2000a,b), and characterization of the virus was performed by partial sequencing of SAV E2 and nsp3 genes as described by Hjortaas et al. (2013). Maximum likelihood phylogenetic analysis was based on multiple alignments of 357 nucleotides of the E2 gene obtained in this study together with reference sequences from GenBank representing all $6 \mathrm{SAV}$ subtypes. The analysis was performed using PhyML (v. 3.00) software (http://phylemon.bioinfo.cipf.es/ phylogeny.html) with GTR plus Gamma model for nucleotide substitution. Clustering support was assessed through 100 bootstrap replicates. Graphic presentation of the phylogenetic tree was performed in MEGA5 Software (Tamura et al. 2007). The nucleotide sequences obtained in this study were deposited in GenBank with accession numbers HG937642 and HG937643.

Furthermore, 2 samples, each containing a pooled tissue homogenate from gill, heart, head kidney, brain and pyloric caeca from 5 fish obtained at the last sampling, were inoculated on Chinook salmon embryo (CHSE-214) cell monolayers for virus isolation and identification by an indirect immunofluorescence test (IFAT) according to the procedure described by Jansen et al. (2010).

A third batch of fingerlings, each at about $30 \mathrm{~g}$, was introduced in October 2013 (Fig. 1). Again, after 3 to 4 wk, typical signs started (Fig. 1). Fish were transferred to the flow-through system, and feeding was stopped for a few weeks. Mortality and growth rate were recorded, but no further diagnostic work was conducted.

\section{RESULTS}

\section{Clinical signs}

In June 2013, approximately $3 \mathrm{wk}$ after the first fish group entered the farming system, about $60 \%$ of fish $(15 \mathrm{~g})$ showed typical signs of $\mathrm{SD}$, i.e. lying on their side at the bottom of the tank. However, when fish were disturbed, they were able to swim. Mortality at that stage was low $(<1 \%)$. Water temperature was around $16^{\circ} \mathrm{C}$, and the fish were still feeding. About $14 \mathrm{~d}$ later, mortality increased and became massive (up to $15 \% \mathrm{~d}^{-1}$ ) due to secondary infections with Ichthyophthirius multifiliis and Flavobacteria resulting in $100 \%$ mortality within 3 to $4 \mathrm{wk}$.

In August, 3 to 4 wk after the second batch of fingerlings entered the system, the disease signs started again. The mortality was around $0.2 \% \mathrm{~d}^{-1}$ for about $4 \mathrm{wk}$, in total about $8 \%$. The fish were then moved to a flow-through system. Feed was stopped for $3 \mathrm{wk}$ and then started again at a lower rate. During the subsequent $2 \mathrm{mo}$, the fish did not gain weight, but some of the affected fish group recovered while growth was still retarded in the remainder.

The third batch of fingerlings that was introduced in October 2013 also developed typical SD signs after 3 to 4 wk. After transfer to the flow-through system and a period without feeding, the mortality was continuously low (approximately $2 \%$ ), but the growth rate was retarded.

\section{Necropsy}

At necropsy, all fish sampled in June and July (Batch 1) were in good body condition, and the length varied between 12 and $19 \mathrm{~cm}$. Parasitologically, a mild to moderate infestation with $I$. multifiliis on the skin was diagnosed. Bacteriological examination revealed the presence of single Flavobacteria on gills and in spleen. Histologically, different lesions were visible in individual animals from the same samplings. In some animals, the pancreatic acinar cells were completely replaced by necrosis, oedema and single inflammatory cells. These lesions were interpreted as acute change. In other animals, the exocrine pancreatic tissue was completely lost (Fig. 2a) with pancreatic ducts and endocrine pancreas being unaffected. There were no signs of fibrosis. In these animals, multiple cardiomyocytes, mainly in the spongy layer of the ventricle and atrium, showed signs of degeneration (Fig. 2c). In these areas multiple myocytes showed enlarged 

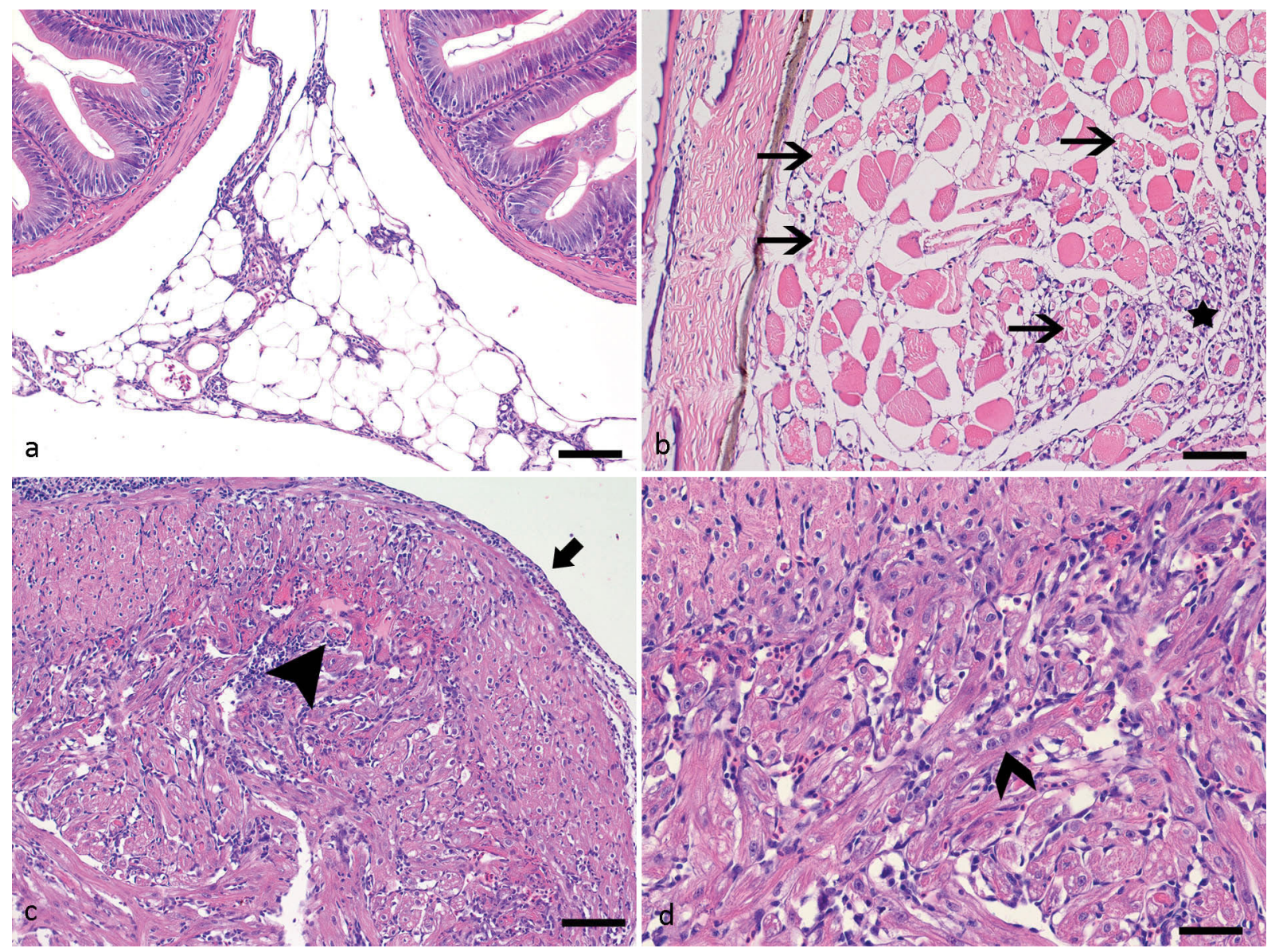

Fig.2. (a) Pancreatic acinar cells were completely lost with pancreatic ducts being unaffected; scale bar $=25 \mu \mathrm{m}$. (b) White muscle tissue showed multifocal degeneration (arrows) and mild infiltration with mainly lymphocyte-like cells (star); scale bar = $50 \mu \mathrm{m}$. (c) Multiple cardiomyocytes, mainly in the spongy layer, showed signs of degeneration (arrowhead); the epicardium was infiltrated with small to moderate amounts of inflammatory cells (arrow); scale bar $=25 \mu$ m. (d) Multiple myocytes showed multiple nuclei (open arrowhead); scale bar $=50 \mu \mathrm{m}$. H\&E stain

nuclei (megakaryosis) or multiple nuclei, indicative of regeneration (Fig. 2d). These changes were interpreted as subacute to chronic change. The degenerative lesions were often accompanied by inflammation with moderate numbers of lymphocyte- and plasma-like cells and less macrophage-like cells in the myocardium and lower numbers of inflammatory cells in the epicardium (Fig. 2c). This stage was classified as chronic. In animals examined in July, white muscle tissue showed multifocal muscle fibre degeneration and mild infiltration with mainly lymphocytelike cells (Fig. 2b).

In animals sampled in August (Batch 2) there were subacute and chronic changes, with almost no degenerative changes present in pancreas and heart. Based on the clinical and histological findings, the presumptive diagnosis of sleeping disease was made.

\section{Virology}

No cytopathic effect (CPE) was observed after inoculation of tissue homogenates onto BF-2, EPC and CHSE-214 cell cultures. The examination of CHSE-214 cell cultures by IFAT gave negative results.

A conventional SDV-specific RT- PCR revealed a single prominent band with a molecular weight of $284 \mathrm{bp}$ in the samples of both diseased fish and the positive control. From fish collected in August, SAV was detected in 3 of 4 samples using a SAV-specific real-time RT-PCR. Cycle threshold values indicated high amounts of virus in one sample. From that sample, fragments of $E 2(488 \mathrm{bp}$ ) and nsp 3 (439 bp) genes were amplified and sequenced. The initial nucleotide blast of the sequences showed that the SAV variant detected in rainbow trout in Switzerland was closely 
related to SDV (Fig. 3). These findings were further confirmed by phylogenetic analysis which placed the Swiss SAV variant within the Subtype 2 clustering together with freshwater isolates from UK and continental Europe. IPN-specific RT-PCR revealed no signal in diseased fish (data not shown).

\section{DISCUSSION}

Here we report the first detection of SD in Switzerland. SAV was identified in tissues from rainbow trout with clinical signs and microscopical changes typical for SD. The detection of SAV was confirmed by sequence analyses showing that the virus was closely related to other freshwater isolates of SAV Subtype 2 previously detected in continental Europe and the UK.
Fish presented with typical signs of an ongoing acute to subacute disease. However, in histology, the majority of fish examined showed chronic changes with inflammation and regeneration. This is in accordance to other reports stating that clinical signs usually are attributed to changes in the red muscle tissue that develop late in the disease process (Boucher et al. 1995, Boucher \& Baudin-Laurencin 1996, Kerbart Boscher et al. 2006). In our case study, clinical signs of disease were present 3 to 4 wk after fish were transferred to the affected fish farming system, earlier than reported in previous studies. A possible explanation for this could be higher water temperature in the current outbreak compared with other reported outbreaks. In our study, water temperature was $16^{\circ} \mathrm{C}$ or above whereas Graham et al. (2007) reported temperature ranging from 8 to $14.5^{\circ} \mathrm{C}$. Furthermore, in natural outbreaks of PD in Norwegian

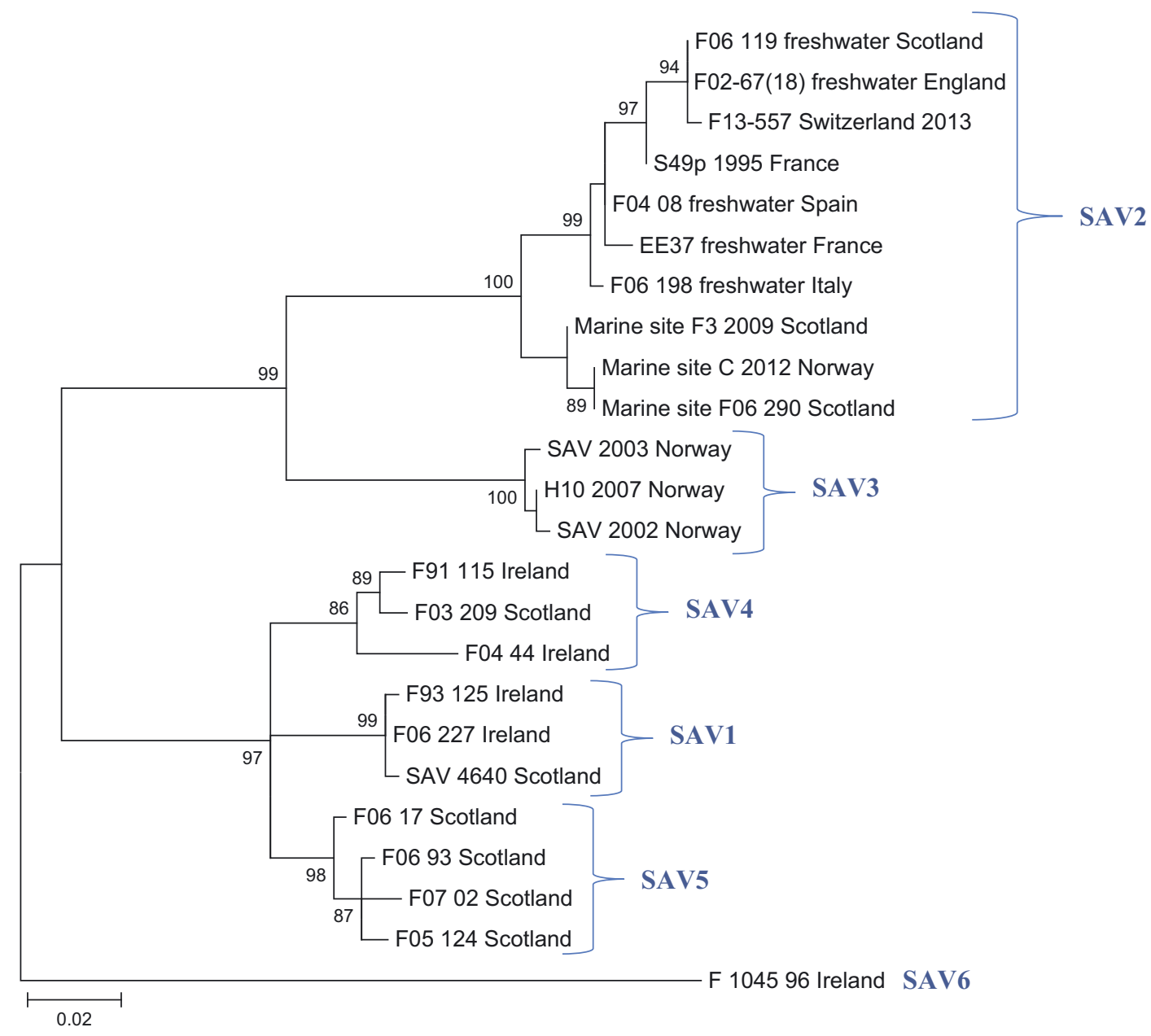

Fig. 3. Phylogenetic tree showing the relationship between salmonid alphavirus (SAV) F13-557 Switzerland 2013 and representative sequences from each of the 6 established subgroups of SAV. The tree was constructed using maximum likelihood and the general time reversible model for nucleotide substitution. Clustering support was assessed through 100 bootstrap replicates 
salmon farms, Stene et al. (2014) showed that sea temperature influenced incubation time. Cohorts exposed to lower sea temperatures had significantly longer incubation periods than cohorts infected when the sea temperatures were higher (Stene et al. 2014).

Virus cultivation was unsuccessful, similar to earlier experiences with primary culture of SAV from infected fish (Christie et al. 1998, López-Dóriga et al. 2001, Graham et al. 2003, 2008, Petterson et al. 2013). Possible causes as low viral loads, virus neutralizing antibodies and/or defective virus particles in the samples have been suggested (Graham et al. 2010, Petterson et al. 2013). Challenges associated with primary isolation of SAV are also in accordance with our unpublished data from attempts to cultivate the virus from several outbreaks of PD in Norway. Nevertheless, the negative results of cell culture examinations on a range of cell types strengthens the view that other cultivable fish pathogenic viruses, including IPNV-virus, did not contribute to the problems in the fish farm. The origin of SAV in the case presented here remains unknown. After the first outbreak of disease, the virus possibly became established at the site, and disinfection methods were probably insufficient.

The fairly high mortality that initiated the diagnostic examinations in this case was probably correlated to I. multifiliis or Flavobacteria. The influence of stress to increase mortality induced by I. multifiliis infestations is well known (e.g. Ewing et al. 1982, Davis et al. 2002). After these secondary stressors were removed, mortality declined and stayed around 2 to $8 \%$. However, growth rate was still reduced, indicating that $\mathrm{SD}$ is of significant economic importance for fish farmers.

\section{LITERATURE CITED}

Anacker RL, Ordal EJ (1959) Studies on the myxobacterium Chondrococcus columnaris. I. Serological typing. J Bacteriol 78:25-32

Boucher P, Baudin-Laurencin F (1994) Sleeping disease of salmonids. Bull Eur Assoc Fish Pathol 14:179-180

Boucher P, Baudin-Laurencin F (1996) Sleeping disease and pancreas disease comparative histopathology and acquired cross-protection. J Fish Dis 19:303-319

Boucher P, Le Ven A, Baudin-Laurencin F (1995) Transmission experimentale de la maladie du sommeil: histologie et caracterisation de l'agent infectieux. Nouv Sci Technol 13:115-117

Branson E (2002) Sleeping disease in trout. Vet Rec 150: $759-760$

Castric J, Baudin-Laurencin F, Brémont E, Jeffroy J, Le Ven A, Béarzotti M (1997) Isolation of the virus responsible for sleeping disease in experimentally infected rainbow trout (Oncorhynchus mykiss). Bull Eur Assoc Fish Pathol $17: 27-30$

Christie KE, Fyrand K, Holtet L, Rowley HM (1998) Isolation of pancreas disease virus from farmed Atlantic salmon, Salmo salar L., in Norway. J Fish Dis 21:391-394

Davis KB, Griffin BR, Gray WL (2002) Effect of handling stress on susceptibility of channel catfish Ictalurus punctatus to Ichthyophthirius multifiliis and channel catfish virus infection. Aquaculture 214:55-66

Ewing MS, Ewing SA, Zimmer MA (1982) Sublethal copper stress and susceptibility of channel catfish to experimental infection with Ichthyophthirius multifiliis. Bull Environ Contam Toxicol 28:676-681

Fringuelli E, Rowley HM, Wilson JC, Hunter R, Rodger $\mathrm{H}_{\text {, }}$ Graham DA (2008) Phylogenetic analyses and molecular epidemiology of European salmonid alphaviruses (SAV) based on partial E2 and $n s P 3$ gene nucleotide sequences. J Fish Dis 31:811-823

Graham DA, Rowley HM, Walker IW, Weston JH, Branson EJ, Todd D (2003) First isolation of sleeping disease virus from rainbow trout, Oncorhynchus mykiss (Walbaum) in the United Kingdom. J Fish Dis 26:691-694

Graham DA, Jewhurst HL, McLoughlin MF, Branson EJ, McKenzie K, Rowley HM, Todd D (2007) Serological, virological and histopathological study of an outbreak of sleeping disease in farmed rainbow trout Oncorhynchus mykiss. Dis Aquat Org 74:191-197

> Graham DA, Wilson C, Jewhurst H, Rowley H (2008) Cultural characteristics of salmonid alphaviruses - influence of cell line and temperature. J Fish Dis 31:859-868

Graham DA, Fringuelli E, Wilson C, Rowley HM and others (2010) Prospective longitudinal studies of salmonid alphavirus infections on two Atlantic salmon farms in Ireland; evidence for viral persistence. J Fish Dis 33:123-135

Hjortaas MJ, Skjelstad HR, Taksdal T, Olsen AB and others (2013) The first detections of subtype 2-related salmonid alphavirus (SAV2) in Atlantic salmon, Salmo salar L., in Norway. J Fish Dis 36:71-74

Hodneland K, Bratland A, Christie KE, Endresen C, Nylund A (2005) New subtype of salmonid alphavirus (SAV), Togaviridae, from Atlantic salmon Salmo salar and rainbow trout Oncorhynchus mykiss in Norway. Dis Aquat Org 66:113-120

Jansen MD, Wasmuth MA, Olsen AB, Gjerset B and others (2010) Pancreas disease (PD) in sea-reared Atlantic salmon, Salmo salar L., in Norway; a prospective, longitudinal study of disease development and agreement between diagnostic test results. J Fish Dis 33:723-736

Karlsen M, Hodneland K, Endresen C, Nylund A (2006) Genetic stability within the Norwegian subtype of salmonid alphavirus (family Togaviridae). Arch Virol 151: 861-874

$>$ Kerbart Boscher S, McLoughlin M, Le Ven A, Cabon J, Baud M, Castric J (2006) Experimental transmission of sleeping disease in one-year-old rainbow trout, Oncorhyncus mykiss (Walbaum), induced by sleeping disease virus. J Fish Dis 29:263-273

Lester K, Black J, Bruno DW (2011) Prevalence of salmonid alphavirus in Scottish fish farms from 2006 to 2007. Bull Eur Assoc Fish Pathol 31:199-204

> López-Dóriga MV, Smail DA, Smith RJ, Domenech A, Castric J, Smith PD, Ellis AE (2001) Isolation of salmon pancreas disease virus (SPDV) in cell culture and its ability to protect against infection by the 'wild-type' agent. Fish Shellfish Immunol 11:505-522 
McLoughlin MF, Graham DA (2007) Alphavirus infections in salmonids - a review. J Fish Dis 30:511-531

Munro ALS, Ellis AE, McVicar AH, McLay HA (1984) An exocrine pancreas disease of farmed Atlantic salmon in Scotland. Helgoland Wiss Meeresunters 37:571-586

Petterson E, Stormoen M, Evensen O, Mikalsen AB, Haugland O (2013) Natural infection of Atlantic salmon (Salmo salar L.) with salmonid alphavirus 3 generates numerous viral deletion mutants. J Gen Virol 94:1945-1954

Stene A, Bang Jensen B, Knutsen O, Olsen A, Viljugrein HJ (2014) Seasonal increase in sea temperature triggers pancreas disease outbreaks in Norwegian salmon farms. J Fish Dis 37:739-751

Taksdal T, Dannevig BH, Rimstad E (2001) Detection of infectious pancreatic necrosis (IPN)-virus in experimentally infected Atlantic salmon parr by RT-PCR and cell culture isolation. Bull Eur Assoc Fish Pathol 21:214-219

Taksdal T, Olsen AB, Bjerkas I, Hjortaas MJ, Dannevig BH, Graham DA, McLoughlin MF (2007) Pancreas disease in farmed Atlantic salmon, Salmo salar L., and rainbow trout, Oncorhynchus mykiss (Walbaum), in Norway. J Fish Dis 30:545-558

Tamura K, Dudley J, Nei M, Kumar S (2007) MEGA4: Molecular Evolutionary Genetics Analysis (MEGA) software version 4.0. Mol Biol Evol 24:1596-1599

Editorial responsibility: Mark Crane,

Geelong, Victoria, Australia
Vardic Smrzlić I, Kapetanović D, Valić D, Teskeredzić E, McLoughlin MF, Fringuelli E (2013) First laboratory confirmation of sleeping disease virus (SAV) in Croatia. Bull Eur Assoc Fish Pathol 33:78-83

> Villoing S, Béarzotti M, Chilmonczyk S, Castric J, Brémont M (2000a) Rainbow trout sleeping disease virus is an atypical alphavirus. J Virol 74:173-183

- Villoing S, Castric J, Jeffroy J, Le Ven A, Thiery R, Bremont M (2000b) An RT-PCR-based method for the diagnosis of the sleeping disease virus in experimentally and naturally infected salmonids. Dis Aquat Org 40:19-27

- Weston JH, Welsh MD, McLoughlin MF, Todd D (1999) Salmon pancreas disease virus an alphavirus infecting farmed Atlantic salmon Salmo salar L. Virology 256: 188-195

> Weston J, Villoing S, Bremont M, Castric J and others (2002) Comparison of two aquatic alphaviruses, salmon pancreas disease virus and sleeping disease virus, by using genome sequence analysis, monoclonal reactivity, and cross-infection. J Virol 76:6155-6163

> Weston JH, Graham DA, Branson E, Rowley HM and others (2005) Nucleotide sequence variation in salmonid alphaviruses from outbreaks of salmon pancreas disease and sleeping disease. Dis Aquat Org 66:105-111

Submitted: February 18, 2014; Accepted: May 13, 2014

Proofs received from author(s): August 19, 2014 